\title{
The Beastie Boys: Jews in whiteface
}

\author{
JON STRATTON
}

Cultural Studies, Curtin University of Technology, Perth, Western Australia

E-mail: j.stratton@curtin.edu.au

\begin{abstract}
The Beastie Boys are usually described as the white hip hop group who helped break rap to a broad-based white audience. Rarely is it acknowledged that the Beasties all came from Jewish backgrounds. This article examines the implications of the Beastie Boys' Jewishness. The Beasties can be placed in a long history of Jewish entertainers reworking black music for white American audiences. By the 1980s, Jews in the United States had been assimilated into whiteness, yet it is clear that the memory of discrimination lived on. The members of the Beasties played with whiteness - performed in whiteface - while being very aware of their own Jewishness and the implications of this. With the advice and mentoring of African American Russell Simmons and the Jewish Rick Rubin, the group gained respect in the black community as legitimate rappers and then set out to perform as uncivil rock performers for white audiences. This article argues that the Beasties' Jewishness was central to their success as the group that brought rap to a mainstream white American audience.
\end{abstract}

\section{Introduction}

I don't recall race ever being an issue per se. Remember, this is a group that was recording for a label run by a Long Island Jew and a black guy from Hollis, Queens, and managed by an Israeli. (Bill Stephney quoted in Alan Light 2005, p. 75)

The Beastie Boys were the breakthrough 'white' rap group. Released in late 1986, their first album, Licensed to Ill, was the first rap album to top the Billboard charts. It went platinum in two months and, by 2001, was nine times platinum having sold around ten million copies in the United States alone. However, the Beastie Boys did not start out as a rap group. In their first incarnation, formed in 1981, the band played post-punk hardcore. In the racialised music politics of American culture, hardcore, like its punk predecessor, is coded white. The Beastie Boys engaged with the genre but kept a certain, humorous distance. In an intriguing prefiguring of their relationship with rap, the band was picked up by vocalist H.R., of possibly the only AfricanAmerican hardcore band, Bad Brains, and opened for them at the final night of the New York club, Max's Kansas City. ${ }^{1}$ Bad Brains played a mixture of hardcore and reggae.

By 1985, when the Beastie Boys made the single 'She's On It' and opened on Madonna's first tour, John Berry had left and been replaced by Adam Horovitz. Moreover, through the urging of Rick Rubin, one of the co-founders of Def Jam and producer of Licensed to Ill, Kate Schellenbach, the drummer, had been edged out also. By this time, then, the Beastie Boys had become a trio of young, upper-middle class, 
male Jews. All three were born and brought up in New York and, as Alan Light notes, 'all had parents involved in the creative professions' (Light 2005, p. 17). Adam Yauch, 'MCA' (born 5 August 1964), had an architect father and a mother who was a public school administrator. The parents of Michael Diamond, 'Mike-D' (born 20 November 1964), were art dealers. Light quotes a Capitol Records staffer telling how Diamond remarked to the company's president: 'I think that you bought a Braque from my father once' (Light 2005, p. 17), Adam Horovitz, 'AdRock' (born 31 October 1966), was raised mostly by his mother, a painter who also ran a thrift store. His father is the highly regarded playwright, Israel Horovitz.

As will be becoming clear, this is not an article about rap and hip hop as such. There is now a large literature on hip hop and its relation to the traditions of African-American music (see, for example, Rose 1994; Krims 2000; Neal and Forman 2004). I am concerned here with hip hop as an expression of African Americanness but primarily as this relates to the work of the Beastie Boys. What I want to tease out is how the Jewish backgrounds of the Beastie Boys made them the ideal group to take rap to a white American audience. This article, then, is written from a Jewish perspective not an African-American, or indeed a white, perspective. One of my interests is to think through how the Beasties, young middle-class Jews, took on a role typical of Jewish entertainers in the United States for almost a century, that of mediating between African-American music and a white audience. A mediation, we must bear in mind, full of power effects. One element in the Jewish relationship with Black culture has been blackface. As Michael Rogin writes: 'Jews - Al Jolson, Eddie Cantor, George Jessel, George Burns, Sophie Tucker - had pretty much taken over blackface by the turn of the century, Jewish songwriters - Irving Berlin, George Gershwin, and Jerome Kern to name only the most famous - created melting-pot American music in the Jazz Age from African American sources' (Rogin 1996, p. 16). The Beastie Boys never performed in a version of blackface but, as we shall see, rather in what I will call whiteface.

Jews were also involved in the Civil Rights movement. From the 1960s, African Americans began to question that involvement. In 1966 the Student Non-Violent Coordinating Committee expelled all white - including Jewish - staff and volunteers. As we shall see, by this time Jews had been whitened though, as we shall also see, this did not mean that there was no longer discrimination against them. However, there is not room in this article to discuss explicitly how Civil Rights politics in the 1980s affected the positioning of the Beasties. As I have remarked, my primary concern is to tease out the Jewishness of the Beasties and think through the complex relation of this with the more fundamental racial divide in the United States, that constructed as between Black and white. Thus, as I will argue, the Beasties played with whiteness, putting on whiteface while taking seriously their indebtedness to African-American culture and becoming accepted as rappers by Black audiences. This, in itself, signals a power dynamic which will surface occasionally through this article but which, as with the broader context of Jewish, African-American and white relations, I have no space to discuss in detail.

On the subject of race I need to make clear at the start that I am assuming race to be a discourse, and that race is not an essential quality of a person. Race is constructed and gains much of its force from the claim to being an essential property of a person. Through this article we shall see the effects of the whitening of Jews in the United States after the Second World War. This was during a time when race has continued to be understood in America as a defining quality of an individual. 


\section{How Jewish was Def Jam}

The Beasties, as they are colloquially known, became friendly with Rick Rubin, who is also Jewish, through Horovitz. Rubin's father owned a wholesale shoe company and the family lived in predominantly white Lido Beach, a small residential barrier-island community on Long Island. At school Rubin played guitar in a punk band called the Pricks. Setting aside, but never letting go of, his liking for punk and heavy metal, Rubin became interested in hip hop by way of the African Americans at his school. However, when he went to New York University to study film and video in 1981, he started an art-noise band called Hose. Rubin recorded the band in 1982 and put the first version of the Def Jam logo on the record's sleeve. ${ }^{2}$ By this time Rubin was also putting on concerts. His parents supported his entrepreneurial activities. In December 1983 , with $\$ 5,000$ of his parents' money, Rubin produced his first rap single, T. La Rock's 'It's Yours' (Gueraseva 2005, p. 28). Horovitz helped out, including writing some of the lyrics.

Rubin met Russell Simmons at a party in a club in 1984 for the premiere of the very short-lived hip hop television show called Graffiti Rock. ${ }^{3}$ By this time Simmons was the foremost hip hop promoter in New York and was running Rush Productions. Def Jam became their jointly run record label. Simmons was born in 1957, about the time his family moved to the middle-class Black suburb of Hollis. His mother was a pre-school teacher and his father, a teacher, subsequently became a professor of Black history at Pace University (Ogg 2002, p. 4).

In his book on the importance of Jews in the development of rock'n'roll, Michael Billig makes the point that the Jewish presence in rock music was to be found predominantly in song writing and producing. He argues that: 'The Jews, who helped to create rock, were growing up as Americans but still were catching the tail-ends of a long history of anti-Semitism' (Billig 2000, p. 13). Jews were able to make their creative mark where they were less visible, where it was not obvious that so many of them did not fit the dominant image of white Americans as light-skinned, blue-eyed northern European. Billig argues that at a time when there was still 'massive segregation in the deep South':

Who better ... to make the fusion than Jews, who were distancing themselves from their own cultural heritage? The music of the synagogue was to play little part in rock's history. By contrast, the Jewish musical innovators could play with the musical heritages of gospel, blues and country music, moving easily from one to another. (Billig 2000, p. 14)

A generation on, Rubin, with his unusual liking for both hip hop and hardcore, for cutting edge musics that were identified as distinctively African American and as white, fits a similar pattern. Not, though, quite the same pattern. However ambiguously, and we must come back to this, Rubin, like the members of the Beastie Boys, was of a Jewish generation that was interpellated into American society as white. For all four of them, their first musical love was hardcore. For none of them, though, was this enough, and this was more the case with the urban Beasties than for the more assimilated, suburban Rubin. Rubin, embedded in white American popular music, would sign the heavy metal band, Slayer, to Def Jam in 1986 and, after leaving the label in 1988, would go to produce four celebrated albums with the doyen of country music, Johnny Cash, on his American Recordings label - a name which nevertheless suggests Rubin's uncomfortable relationship to his assimilated Americanisation in its overt invocation of the United States. 
Equally, it is notable that Simmons' cultural background was not as straightforwardly African American as might be supposed. Certainly, Alex Ogg tells us, Simmons' father 'talked at great length about civil rights and black empowerment and encouraged his offspring to take part in demonstrations' (Ogg 2002, p. 5). Ogg also writes that:

As a youth Simmons' musical tastes had been informed by New York's WWRL station, which featured several of the jive-talking DJs who, depending on your view of history, either inspired hip hop or jumped on the bandwagon as it began to pick up velocity. Simmons' tastes, he claims, were geared towards the hard-bitten street soul of The Dells and Moments rather than Motown's more ornate, pop-oriented fare. (Ogg 2002, p. 6)

While this establishes Simmons' African-American street credibility, we also know that, when he was young, Simmons used to enjoy watching Elvis Presley films on television on Saturday and Danny, his elder brother, recalls: 'Russell really, really, loved Elvis Presley. He used to imitate him dancing and singing' (Gueraseva 2005, p. 21). This suggests an early familiarity with, and liking for, the white rock tradition which, after all, has a heritage in rhythm and blues. Later, with the Beasties, Simmons would strive for the cross-over success of rap that Sam Philips wanted Presley to achieve with rhythm and blues.

Moreover, Simmons did not go to one of the local African-American schools. His parents insisted he attend an integrated school with better academic standards (Ogg 2002, p. 5). In an interview with Cedric Muhammad, Simmons explained what this meant:

I mean, when I grew up I was bussed to a Jewish school and I didn't know why the WASPs (White Anglo-Saxon Protestants) would chase me into this one particular area of projects.... and I didn't know why this one group of White people were chasing me and this other group were protecting me. But it was because I was a Jewish co-op. (laughter). So I have a relationship with them. (Simmons interviewed by Cedric Muhammad at BlackElectorate.com)

He may not have been Jewish but the white-dominated, discriminatory social order of the 1960s meant that Simmons found himself making common cause with Jews and he came to see them, as the WASPs did, as distinct from other white people. It is not surprising, then, that Simmons would agree to a partnership with Rubin or that he would show the way by taking the Beastie Boys seriously as a rap act. From Simmons' perspective there appears to have been a sense that, in terms of the binary-based, racialised social order, Jews had much in common with Blacks while, discursively, Jews were placed within the category of white. ${ }^{4}$ Simmons appears to have understood that a Jewish hip hop group would be ideal for making hip hop's cross-over to a white audience. Indeed, after the Beasties left Def Jam, Simmons replaced them in 1988 with $3^{\text {rd }}$ Bass - two MCs and an African-American DJ. Both the MCs, MC Serch (Michael Berrin) and Prime Minister Pete Nice (Peter Nash) were Jewish. ${ }^{5}$

Rubin was by no means the only prominent Jew in the history of Def Jam outside of its artists. Bill Adler, who was the label's Director of Public Relations is Jewish, as is Lyor Cohen, the son of Israeli migrants, who was given a job by Simmons working in Rush Management, his artists' management company. From there Cohen rose to become CEO of Island/Def Jam in December 2001. In 1985, Cohen had even shared an apartment with Simmons (Gueraseva 2005, p. 59). As Stacy Gueraseva writes: 'It was Cohen who figured out how to maximise profits at Rush and Def Jam through clever marketing ideas and endorsement deals' (ibid., p. 95). He was central to the financial success of Rush and Def Jam. This entrepreneurial collaboration between Blacks and Jews was by no means unique. Nelson George remarks that the 'majority of [white] 
men and women [involved in record companies associated with early hip hop] were Jews who carried on a long tradition of black and white collaboration in grassroots music that stretches back, at least, to the '40s when Jewish record men like Leonard and Phil Chess in Chicago and Jerry Wexler in New York led the pioneers who put electrified blues and R\&B on vinyl' (George 1998, p. 58). Def Jam's Jewishness, though, made it an ideal platform for the Beasties with their ambiguous relation to whiteness.

\section{Jews and whiteness}

What is becoming apparent here as a context for discussing the Beasties is the ambiguous status of Jews as they became accepted into whiteness. Karen Brodkin writes that: 'By the late 1940s, not only did economic and social barriers to Jewish aspirations fall away but the United States, perhaps in part from guilt about having barred Jews fleeing the Holocaust, became positively philo-Semitic in its embrace of Jewish culture' (Brodkin 1998, p. 141). Matthew Frye Jacobson argues similarly that: 'Changes wrought in the US social order by the war itself and by the early Cold War, too, helped to speed the alchemy by which Hebrews became Caucasian' (Jacobson 1998, p. 188). While it is correct that in formal, institutional areas Jews, like European groups such as the Italians, were increasingly thought of as white, culturally limitations remained on their acceptance. Thus, for example, Billig reminds us that:

In the 1950s, but also well into the 1960s, America, in its public display, seemed to be a White Anglo-Saxon Protestant culture. Heroes and heroines had suitably blond hair and creamy skin. (Billig 2000, p. 9)

Acceptance as white meant, in the main, assimilation to Anglo-American norms. To succeed as individuals in the domain of the public meant that Jews, like members of other white 'ethnic' groups, had to become invisible and, ideally, any sense of the Jews as a grouping would have to disappear.

Norman Kleeblatt suggests that: 'The Jewish community . . . achieved visible success while its individual members were becoming invisible' (Kleeblatt 1996, p. 5). However, it was the preservation of that sense of a 'Jewish community' which marked the failure of the American assimilation of Jews into Anglo-American whiteness. Writing about art, Kleeblatt notes that: 'The 1980s witnessed the emergence of Jewish themes among a group of mainstream, predominantly secular artists' (ibid., p. 6). Here, we are at the beginning of the multicultural backlash against an assimilatory project that never made space for Jewish difference.

Brodkin, who has traced this Jewish whitening from the Jewish point of view, discusses how 'Jewish whiteness became American whiteness' (Brodkin 1998, p. 168). It would be better to think about how American whiteness took on elements of Jewishness and thus appeared to be making space for Jews when, in reality, American whiteness was simply practising a version of colonial appropriation of the culture of the colonised. As David Biale, Michael Galchinsky and Susannah Herschel point out, Jews have been 'anxious about multiculturalism' (Biale et al. 1998, p. 5). One reason they give for this is:

the consciousness Jews have of themselves as occupying an anomalous status: insiders who are outsiders and outsiders who are insiders. They represent that boundary case whose very lack of belonging to a recognisable category creates a sense of unease. (ibid., p. 5) 
It is the case, as Brodkin and Jacobson and others argue, that by the 1960s and 1970s, Jews in the United States were discursively constructed as white. However, as Billig and Biale et al. signal, this is not the whole story. Jews were also considered to have qualities - perhaps it would be better to say they continued to be considered to have qualities - which marked them as different from other whites and, indeed, might place them outside of whiteness. Recognising that Jews were understood discursively to be white while, in practice, they were thought of in an ambivalent way at various times as either white but different or as not white at all, is a way of understanding Biale et al.'s description of Jews as a boundary case and as both insiders and outsiders. It is, as we shall see, this structure which provided the context for the Beasties' performance of whiteface and, climaxing in Licensed to Ill, the sometimes unrecognised humour that itself was founded on distantiation and unsettlement - the experience of both belonging and not belonging, being accepted and being set apart. References to the Beasties collapse race into colour and describe the group as 'white', and only secondarily, and rarely, as Jewish.

At the same time, the whiteness of the Beastie Boys, like whiteness in general in the United States, was governed by its relation to blackness. It is worth quoting D.M.C., of the Black hip hop group Run-D.M.C., here:

From day one they [the Beasties] was killing. Even when nobody knew them. It could be a completely black, Negro, Southern crowd, there to see Run-D.M.C. and Whodini and their favorites. But when the Beasties came on, it wasn't like people were walking around getting hot dogs, they really paid attention to them white boys. (D.M.C. quoted in Light 2005, p. 74)

This quotation reminds us that the Beasties were taken seriously as rap artists by black audiences, something that Simmons had been determined should happen, and that they were seen, literally, as white - white, here, structured in opposition to blackness. In the post-Second World War era the broadening of the category of white to include Jews and various European national groups was founded in the reassertion of the fundamental difference of the category of blackness. Brodkin writes that:

When directed at blackness, the discourse of ethnicity produced its own, new, cultural variety of racism, which prevails today. Instead of asserting the inherent biological inferiority of some races, it asserted the inherent cultural inferiority of some ethnicities. (Brodkin 1998, p. 154)

She goes on to note that: 'The entitlements of whiteness depend upon their denial to non-whites' (ibid., p. 154).

To understand this construction of blackness as the Other of white we can look at the so-called 'one drop rule'. Put simply, the assumption in the 'one drop rule' is that having any African-American ancestor, no matter how far back, classifies a person as black, as being positioned within the category of blackness. It is, then, an anchor point in the essentialist construction of race. Katya Gibel Azoulay has traced the history of this idea in the laws relating to the offspring of mixed sexual relations during the colonial period (Azoulay 1997, pp. 90-1). Azoulay goes on to write about the importance of the one drop rule in the present: 'Although the social definition of being Black, imposed by the one drop rule, was adopted as an affirmation of a political identity during the 1960s, the very expression "to look white" indicates the explicit invention of a category whose meaning cannot exist on a visual level but only as an ideological construct' (ibid., p. 91). Her point here is concerned with the ideological construction of the category of 'black' and with membership of that category. As Azoulay writes elsewhere, "the social custom of applying the "one drop rule" has endured in the public imagination - among both american (sic) Blacks and whites' 
(ibid., p. 2). The continued acceptance of the one drop rule ensures that there is no blurring in practice of the culturally constructed binary structure of 'white' and 'black'.

Biale et al. describe Jews as '[s]tanding somewhere between the dominant position of the white majority and the marginal position of people of color' (Biale et al. 1998 , p. 5). However, they remained discursively interpellated as white and differentiated from African Americans and blackness. Writing about Jewish blackface in the early years of the twentieth century, and in particular on Al Jolson's blackface in The Jazz Singer (1927), Michael Rogin remarks that: 'Jews acquired American credentials by, in this racially divided society, taking control of the black role' (Rogin 1996, p. 17). In this way they could differentiate themselves from African Americans.

\section{The Beasties and blackface}

While the Beastie Boys mastered a black musical form they did not perform it in a version of blackface. As I have remarked, the Beasties' juvenile recordings were in the genre of hardcore. Released in 1982, Angus Batey, in his biography of the band, describes the Pollywog Stew E.P. as: 'An amateurish slew of fuzztone guitars, bluebottle bass and shouting' (Batey 1998, p. 18). The music shows the influence of the harder English punk bands, not so much the Sex Pistols but Motörhead, whose title for their 1981 live album, No Sleep 'Til Hammersmith, would be the inspiration for the Beasties' song title 'No Sleep Till Brooklyn' (1986). Recognising this influence, it is also possible to discern certain linguistic inflections that suggest an attempt at an English accent. The band, it seems, were looking for a voice.

The following year the Beasties released the Cookie Puss E.P. 'Cookie Puss' itself was the Beasties' first experiment with hip hop. A Cookie Puss was a speciality ice-cream cake made by the Carvel Ice Cream company. The Beasties made a prank phone call to the company in which they ask the female employee for a person called Cookie Puss. Cut up, laid onto a beat, and with various additional phrases, the recording of the phone call forms the basis of the track. In 1987, Yauch explained that:

We went into the studio and we did the song 'Cookie Puss' as a joke. We were making fun of Malcolm McLaren and the whole downtown art scene that was exploiting hip hop. (Beastiemania.com)

In 1983 McLaren, who had managed the Sex Pistols (and who also happens to be Jewish, see Stratton 2007), had released Duck Rock. On 'Buffalo Gals' (which was written in 1844 for a blackface minstrel show though the music is traditional) there is the repeated line: 'All that scratching is making me itch' which is echoed on 'Cookie Puss' with 'These pussy crumbs are making me itch!' and 'Maybe I should scratch', so Yauch's assertion may be right. ${ }^{6}$ However, any humorous bathos intended by making a track about an ice-cream cake thought to be a person is undermined by the aggression and sexism of the call which are reinforced by the Beasties' use of AfricanAmerican street slang, as in 'The shit with this bitch', and, especially, their adoption of a New York African-American accent. The music magazine Creem described the track as 'a sexist and racist stylus-scratch rendering of a pornographic phone call to an ice-cream sandwich store' (Beastiemania.com).

At the core of the perception of racism was the 'blackface' imitation of an African-American accent. The temptation to use such an accent remained. Three years later, about the time of Licensed to Ill, there was discussion about Michael Diamond being asked to leave the group. According to Bill Stephney: 
The thing is, if you had Ad-Rock and Yauch as they were back then, they could have crossed the line a lot of white rappers unfortunately cross, which is trying to sound black. Mike D was, out of the three of them, the one who sounds - I don't want to say whitest, but most conversational; he was trying the least to sound like the black rappers. (Stephney quoted in Light 2005, p. 86)

Stephney describes the Beasties as 'white rappers'. One comparison here would be with Vanilla Ice who, in 1990, had a number one album with To the Extreme on the back of the success of 'Ice Ice Baby'. Ice, '[a]towering southerner with an Aryan chiselled jaw', had 'a stiff rhyme flow and awkward use of rap slang ... [and appropriated] African-American college chants for "Ice Ice Baby" ' (Diehl 1999, p. 124). Ice attempted to gain credibility with a white suburban teen audience by imitating Black rappers. In doing so he lost respect in the Black community and in turn lost his status with the white audience that valued hip hop authenticity in relation to acceptance by African Americans.

Stephney thinks of the Beasties' accents as white but it is more complicated than this. Certainly, and especially on Licensed to Ill, their accents can be read as those of petulant, white American teenagers. Matt Diehl writes about the success of '(You Gotta) Fight For Your Right (To Party)' with white suburban teens that the Beasties had, 'rhyme styles that flaunted and emphasized white nasal speech patterns' (Diehl 1999, p. 123). However, there is a Jewish element to this also. Mike Rubin has suggestively described the Beasties as having, 'a nasal Jerry Lewis-like delivery' (Rubin 1999, p. 126). As this reference to the Jewish Lewis suggests, the accents also conjure up the Jewish caricature of the whiney, emasculated young man forever in thrall to his overbearing Jewish Mother. The social historian, Riv-Ellen Prell, has explained how, in the post-World War II period, the Jewish Mother stereotype took on a new form: 'this representation of New World prosperity was an American-born Jewish Mother who pushed, wheedled, demanded, constrained, and was insatiable in her needs and wants' (Prell 1999, p. 143). She goes on to describe how, in this stereotype, the Jewish Mother's 'excessive and dangerous nurturance held back her sons ... from moving forward into adulthood' (ibid., p. 150). In a reading based on this context, the Beasties can be read as young Woody Allen-type characters.

We need to discuss this aspect of the Beasties' image in more detail. Commenting on their performance on the tour to promote Licensed to Ill, Dave Hill wrote that:

What the Beasties contrive is half low Animal House humour and half lumpen role playing. So spectacularly impotent is their libidinal posturing that the offensiveness of having caged go-go dancers on stage comes close to symbolising their comprehensive uselessness to any sane female person. (Dave Hill quoted in Batey 1998, p. 84)

Daniel Boyarin tells us that: 'The topos of the Jewish man as a sort of woman is a venerable one going back at least to the thirteenth century in Europe' (Boyarin 1997, p. 211) and he writes about 'the consistent representation of male Jews in European culture as female, largely because of their circumcision, which was interpreted as feminization' (ibid., pp.211-12). Boyarin goes on to discuss male Jewish 'selffeminization' though in the American situation we can, perhaps, simply think in terms of the internalisation of a dominant stereotype.

Following on from the circumcision reference we can note that the Beasties do seem to have had a preoccupation with penis size. Ogg notes that:

In the mid-Eighties, discussion of the enormity of one's male appendage was routine. The Beastie Boys discussed it more than most. (Ogg 2002, p. 55) 
This, though, was not enough. When the Beasties went on their Licensed to Ill tour in the United States, in addition to the go-go girls in cages that Hill mentions, they had a twenty-one foot penis that erected out of a box. Another account suggests the penis was twenty-five feet. ${ }^{7}$ The Beasties may well have been 'sampling' here as the Rolling Stones toured the United States with a giant inflatable penis in their show in 1975. The Stones' version was twenty feet. Mick Jagger used to straddle it during the group's performance of 'Star Star', a song about a groupie. Writing about Freud's 'Dora' case, Sander Gilman remarks that: 'Central to the definition of the Jew - here to be always understood as the "male" Jew - is the image of the male Jew's circumcised penis as impaired, damaged, or incomplete and therefore threatening' (Gilman 1991, p. 96). In the psyche of the Beasties, this appears to have translated into a real or humorous, most likely both, anxiety over their manhood such that they needed to have an artificial penis larger than that of the band that had, in 1969, with macho bravura been billed as 'The Greatest Rock and Roll Band in the World'. We can read this preoccupation with penis size as a combination of Jewish Mother emasculation and the cultural feminisation associated with anxieties over circumcision.

\section{Jewish/white/black}

The title of Licensed To Ill can be read in three different ways. ${ }^{8}$ The first is an allusion to the suavest and most sophisticated of white spies, the English James Bond who, as 007, was 'licensed to kill'. The second is a reference to that emasculated Jewish son - or sons, if we understand this as a reflexive reference to the Beasties - who enjoins his mother's love and chicken soup through hypochondria. He is, if you like, allowed to be sick so that his Jewish Mother can have an excuse to nurture him even more. The third reading refers to the African-American usage of ill having a positive sense of 'good' or 'crazy' in something like 'acting crazy'. 'Licensed to ill' could then mean something like being given permission to act crazy. Given that the expression is African American, it would suggest that these white Jews have been given the approval of the African-American community. These three meanings reflect the three voices of the album but it is important to acknowledge that the African-American voice is present in the form of the music, hip hop and rap, not in any blackface mimicry. No matter how much the Beasties' Jewishness unsettled their whiteness, they remained discursively positioned within that category.

Before leaving this point there is one more story to be told. In 1986 the Beasties toured as the opening act for the Def Jam Raising Hell package which also included Whodini, LL Cool J and, of course, Run-DMC. One performance was at the Apollo Theater in Harlem. As Dr Dre, ${ }^{9}$ the Beasties' DJ at the time, tells the story:

Everybody was like, 'Look whatever you do don't say "nigger" ' - because it was a part of what we did, before a lot of people were doing that in hip hop. They didn't mean it in a negative way, they meant it as something warm and generous to their audience. But Russell grabs me and says, 'Don't let them do it'. And I'm like, 'What am I going to do? I'm in the back DJing'. So they're out there doing 'She's On It' and Ad-Rock says, 'All you niggers, wave your hands in the air!' 'I've never seen so many blank stares!' (Ogg 2002, p. 58)

The Beasties finished the song and then got off stage as fast as possible. As Jews within whiteness the Beasties could play with their speaking positions. However, when white is still constructed as the Other of black, it is not possible to unsettle blackness from the position of whiteness. The Beasties were accepted by black audiences as rap artists precisely because they did not attempt to be black. When they tried to play the 
same game of transgression and ambiguous positioning that worked with white audiences on a black audience all it did was reinforce, indeed bring to the fore, their positioning as white. While Simmons understood the problematic construction of Jews as white, and therefore also understood the Beasties humorous performance of whiteness, the bulk of the Beasties' African-American audience quite literally took them seriously as rap artists. When the Beasties started calling the Apollo audience 'niggers', that audience saw white men abusing them - which Simmons must have foreseen when he attempted to get the Beasties not to use the word.

We can clarify the structure of the Beasties' relationship to the racial category of black by thinking about a cabaret skit they used to perform. The Beasties, like many people into hip hop, used to frequent a downtown Manhattan club called Danceteria. Every Sunday the club put on an informal cabaret called No Entiendes. One sketch the Beasties performed during 1985 was called 'Three Bad Jewish Brothers'. It highlighted the Jewishness that was always left ambiguous - could be read or not read by audiences - in their official performances. In 'Paul Revere', for example, a track on Licensed to Ill, the Beasties describe themselves as 'three bad brothers', leaving out their specifically Jewish identification. In 'Three Bad Jewish Brothers' the Beasties:

dressed up in Hasidic clothes and performed renditions of Run-DMC songs. With a friend deejaying in the background Cey Adams would lay down the basic part of the rap, and the Beasties would do Jewish phrases, like 'We are three Jewish brothers/We rock the house and we turn it out. Oy!' (Gueraseva 2005, pp. 57-8)

Adams is an African American who has worked as a graphic designer with the Beasties since their 'Cookie Puss' days. Gueraseva describes the Beasties' skits as hilarious and cites this one as, '[t]heir most famous'.

Run-D.M.C. were Simmons' younger brother, Joseph, and his friend Darryl McDaniels. In the spring of 1983 Russell Simmons and Larry Smith produced the group's first single, 'It's Like That', backed with 'Sucker MCs'. As Stephen Thomas Erlewine writes: 'The single sounded like no other rap at the time - it was spare, blunt, and skilful, with hard beats and powerful, literate, daring vocals, where Run and D.M.C'.s vocals overlapped, as they finished each other's line' (Erlewine). Simmons managed the group himself but, this being before the advent of Def Jam, signed them to Profile. 'It's Like That' became a Top Twenty R'n'B hit. Run-D.M.C. transformed rap music by pulling forward the rhythm track and emphasising the beat. The crunching beat, which became increasingly highlighted in their music, moved rap closer to rock music. Simmons' early liking for Elvis Presley was paying off! Rubin, who had not yet met Simmons, enthused over the single: 'This is the real shit', he proclaimed, and then: 'I could do this better' (Gueraseva 2005, p. 13). Run-D.M.C.'s eponymously titled first album was released in 1984. In 1986 Rubin (along with Simmons) would produce the group's third album, Raising Hell, and get Run-D.M.C. to cover hard rock band Aerosmith's 'Walk This Way' upon which that band's Steven Tyler and Joe Perry collaborated. As a single, Run-D.M.C.'s version got to number 4 on the Billboard chart and ranked number 89 in Billboard's Top 100 singles of 1986. The track broke rap to that white, suburban teen audience that Simmons and Rubin wanted to reach. Raising Hell went on to sell three million copies.

With Licensed to Ill, also produced by Rubin, the Beasties would consolidate Run-D.M.C.'s breakthrough. However, at this point Raising Hell is in the future. The Beasties are interpolating caricatured Yiddish stylings into versions of Run-D.M.C.'s raps. Dressed as ultra-religious Hasidim, the Beasties are not only expressing their 
own Jewishness but they are also secular Jews performing extreme Jewish religious orthodoxy. Read from a Jewish point of view, the Beasties are being 'bad' because they are treating Hasidim humorously, not respecting the gravitas of the Hasidim. From this point of view, in that well-known, anxious phrase, the Beasties are 'bad for the Jews'. At the same time the Beasties might be read as disrespecting Run-D.M.C. and their songs, undermining the seriousness of the lyrics by matching them with a generalised Jewishness which is characteristically thought of as nerdish, bookish, mental rather than physical and more 'female' than macho. Describing Run-D.M.C.'s first album, which contained their early singles, Erlewine writes that:

Where other MCs sounded cheerful, Run and D.M.C. prowl and taunt the listener sounding as if they were a street gang. And while much of the record is devoted to braggadocio, boasting and block parties, Run-D.M.C. also addressed grittier realities of urban life, giving this record both context and thematic weight. (Erlewine)

Run-D.M.C.'s emphasis on these macho characteristics, although these have a long history in other African-American musical genres such as the blues, had not previously been present in hip hop which had origins as party music. These characteristics would form a key part of the Beasties' image during their Licensed to Ill period. Here, in the 'Three Bad Jewish Brothers' skit, the performance of Jewishness makes obvious and transparent, and straightforwardly humorous, what in their official performances remained ambiguous and subject to double readings.

The alternative meaning of 'bad' in the skit's title derives from the AfricanAmerican reference. In African-American vernacular 'bad' means good. In this reading of the skit's title, these are good Jewish brothers - there is also a play here on the African-American usage of 'brother' meaning, here, someone of the same race. What makes these Jews good is that they are showing respect. Their parody is not of Run-D.M.C.'s lyrics, nor of Run-D.M.C. themselves. More, there is here no parodic or otherwise attempt at an African-American accent, no blackface. Rather, the parody lies in the humorous tension between two quite opposite cultural images. This is funny but it is not the basis for a major career break-through. In general, the white audience that liked 'Fight' and Licensed to Ill so much would not have appreciated what is, fundamentally, a humour based in the juxtaposition of two such different stereotypes. The comparison here is with a group calling themselves 2 Live Jews. The name signals the material as it is a take on the name of 2 Live Crew, the notoriously controversial African-American rap group. 2 Live Jews have actually made four albums but the first is generally regarded as their best. Parodying 2 Live Crew's 1989 album, As Nasty As They Wanna Be, it is called As Kosher As They Wanna Be and was released in 1990. 2 Live Jews, using the names Moisha MC and Easy Irving, develop the image of two aging male Jews living in Miami. With titles like 'J.A.P. Rap' and 'Shake Your Tuchas', what is intended is precisely that clash of stereotypes present in the Beasties' sketch. The audience would have to be knowledgeable in JewishAmerican culture and its stereotypes as well as in hip hop in order to understand and appreciate the humour. Unlike the Beasties' Licensed to Ill which could cross all three racialised groupings, and especially that blurred line from Jews to white male teens, the obvious audience for 2 Live Jews would be much more limited. ${ }^{10}$

Later, for Licensed to Ill, the Beasties would actually record a Run-D.M.C. song. As D.M.C. tells the story:

We recorded 'Slow and Low', we was gonna put it on our album. But they [the Beasties] liked it so much that they wanted to do it. Rick was pressuring us, 'Yo, you gotta let my guys have it'. 
They put their names in there, their favourite stuff - like where we would say, 'We like McDonald's', they would put in 'We like White Castle'. (Light 2005, p. 84)

The Beasties changed the lyrics where necessary to make the song 'theirs' as the singers but they added no lyrics that would make it obvious that the Beasties were Jewish. The Jewishness of the group was submerged in the dynamic of a 'white' reworking of an African-American rap. ${ }^{11}$

In his biography of the Beasties, Rhyming and Stealing, Batey picks up on two lines from 'Slow and Low': 'What you see is what you get/And you ain't seen nothing yet'. The lines appear at the end of the first verse, as it happens immediately after one of the lines the Beasties altered. Batey uses these lines to suggest that the song can be read two ways: '[E]ither as a cocksure boast that the best of the Beasties is yet to come, or as an "accidentally" self-deprecating put-down that suggests that the people in front of you on stage are "nothing", nobodies, and that there is precious little chance of any improvement' (Batey 1998, p.44). Personally I find this second reading unlikely but I am interested in the two lines Batey identifies. 'What you see is what you get' is a long-standing cliché. In this case, though, sung by the Beasties and not by the original African-American writers and singers, it urges a misrecognition. What the majority of viewers/auditors 'saw' was a white group. What they were actually getting was a Jewish group in whiteface and, indeed, that group while apparently describing themselves, rapping a song actually written by a Black group and adapted by the Beasties to describe themselves. The second line can be read as an allusion to a line made famous from The Jazz Singer. Jolson is singing in a club. He finishes 'Dirty Hands, Dirty Face' and then, in the applause, says: 'Wait a minute. Wait a minute. You ain't heard nothing yet' (quoted here from Rogin 1996, p. 81). Jolson goes on to sing 'Toot, Toot, Tootsie'. These are the first spoken words in a film. Rogin tells us that it is an expression Jolson had made his own in vaudeville. At this point in the film Jolson is not in blackface. The Jewish character had changed his name from Jackie Rabinowitz to Jack Robin and is passing as white. Jolson, we should remember, was himself Jewish. We have, then, a Jew playing a Jew masquerading as white. There is no way of knowing what really attracted Rubin and the Beasties to 'Slow and Low' - it can't have been the rhythm track because Rubin created a new one - but there is a clear affinity between Rabinowitz/Robin, performing in whiteface, and the Beasties, with their hip hop names disguising their Jewish names, also performing in whiteface. Jolson, as Robin, later sings in blackface. Unlike other ' white' rappers who, rather than singing in a white American accent, have sought to appropriate what could be heard as an African American accent, the Beasties sing Run-D.M.C.'s rap in their Jewish/ white teen whiney accents. This could be read by knowledgeable listeners as asserting Jewishness while respecting African-American culture.

\section{The Beasties and whiteface ambiguity}

By the beginning of the 1980s the popularity of disco was in rapid decline. A negative feedback loop evolved. As Steve Greenberg writes, on radio, 'backpedaling programmers were shying away from black records of any kind in an effort to stay as far from the "disco" tag as possible" (Greenberg 1999, p. 27). On the Billboard pop singles chart the number of songs that also appeared on the R'n'B chart declined from around 50 per cent in the first half of 1979 to around 17 per cent at the end of 1982 (Greenberg 1999, p. 27). In Greenberg's words: 'A wall had been erected between black and white music, and neither white nor black kids had any idea what the other was listening to' 
(ibid., p. 27). This was the context in which Simmons, Rubin, Run-D.M.C. and the Beastie Boys were making rap records. Bill Adler, who was the publicist for Def Jam in its early days, remembers:

Our rappers existed in the commercial ghetto. I mean, they certainly never got too much radio play - of any kind, black or white, black or rock. They'd play the black crowds, and they'd hit in black media, and although I could break 'em out a little bit, there was no question of crossing over. Not on their own terms. It was not going to happen. And radio, rock radio, was as dismal then as it is now, maybe more. Just dismal. And so that's when we all knew that the Beastie Boys were white, when they put out 'Fight for Your Right' and got added to rock radio right away. (Bill Adler quoted in Light 2005, p. 88)

That the Beasties were actually Jewish, as is Adler, adds a further irony to Adler's statement about when the people at Def Jam ' $\mathrm{knew}^{\prime}$ that the Beasties were white. This acceptance of the Beasties' single by white rock radio was the difference between Raising Hell selling that three million copies and Licensed to Ill's ten million.

The video for Run-D.M.C.'s version of 'Walk This Way' had an image of the wall between rap and rock being broken down. The Beasties, with Rubin, produced a new song which synthesised the key elements of rock and rap in a way which made rap accessible to a white audience raised on rock and the group packaged it in whiteface. Far from Run-D.M.C.'s boasting and bravado, '(You Gotta) Fight For Your Right (To Party $)^{\prime}$ is a song about being oppressed by your parents and your school. Lyrically, it is a rap of teen rebellion. Your mother makes you go to school and throws out your best porno mag. Your father punishes you for smoking so - 'You gotta fight for your right to party'. The lyrics are far from Run-D.M.C.'s boastful rhyming and, later Public Enemy's campaigning for African-American rights. ${ }^{12}$ Similarly, the tone does not have Run-D.M.C.'s punchy aggression. Instead, the tone of the vocals means that 'Fight' is more likely to be read as unthreatening; three whiney teens complaining about how hard their lives are and pathetically encouraging a rebellion over having a party. (A history of the making of 'Fight' is provided by Odell 2004.)

Taken seriously, 'Fight' is an 'oppressed teen' genre song in the tradition of Chuck Berry's 'School Day' and Eddie Cochran's 'Summertime Blues'. However, this muted complaint is sung by three middle-class, urban Jews. In the Beasties' work of this period it is possible to read a tone and accent in the vocalising which undercuts the boasting and general aggression of the lyrics. Nevertheless, as Diamond himself has remarked:

There were tons of guys singing along to 'Fight For Your Right To Party' who were oblivious to the fact it was a total goof on them. Irony is oft missed. (Batey 1998, p. 54)

One reason the irony can be missed is because it could almost not be there. The Beasties' whiteface could almost be for real. Jews in the 1980s were, after all, considered to be white (but never really forgetting that they were also marked within the American racial order as Jews).

For its irony, the best comparison for 'Fight' is the track by the Dictators on their 1974 album, The Dictators Go Girl Crazy!, called '(I Live For) Cars And Girls'. The Dictators were a Jewish proto-punk group who had an important influence on the more well-known Ramones. ${ }^{13}$ 'Cars And Girls' is a Beach Boys pastiche:

Well I'm the type of guy who's into getting high on a Friday afternoon

So now you know I'm a regular Joe and I'll tell you what I like to do

I like to make the scene

In my machine 
I like to leave them in another state

Whenever I accelerate

I live for cars and girls

Once again the irony is ambiguous. It requires knowing that the Dictators are not, and could not be, the Beach Boys (or, indeed, a little anachronistically, Bruce Springsteen, whose first album was released in 1973). We should be reminded of Billig, quoted earlier, about American heroes and heroines having 'suitably blond hair and creamy skin'. Only some Jews can pass. The Dictators, like the Beastie Boys a generation later, were discursively constructed as white but remained Jews.

What powered the Beasties' image at this time, and what made them attractive to those suburban, white, male teens, was the group's apparent incivility. Yauch has claimed that:

It wasn't until 'Fight For Your Right To Party' came out that we started acting like drunken fools. At that point our image shifted in a different direction, maybe turning off the kids that were strictly into hip-hop. It started out as a goof on that college mentality, but then we ended up personifying it. (Yauch quoted in Batey 1998, p. 72)

One of Yauch's points here is about the ambiguity of the group's incivility; that it started out as a performance and ended up becoming real for them. Another point is a subtle description of how the group's audience shifted from those people 'into hip-hop' (African Americans) to those with 'that college mentality' of 'acting like drunken fools', that is, white male teens. It was these teens who took the lyrics of 'Fight' and the other tracks on Licensed to Ill seriously and, in doing so, offered an opportunity for the Beasties to become more securely white and less Jewish. The Beasties' performance of whiteness became real as they became accepted by the white audience.

In Coming Out Jewish I argued, following the pioneering work of John Murray Cuddihy, that what has been central to any assimilation of the Jews into EuroAmerican whiteness has been their acceptance and internalisation of civility. I quoted Kenneth Bolding who, associating civility with civilisation, described the latter as 'characterised by the elaborate systems of religion, politeness, morals, and manners' (Stratton 2000, p. 285). Adler has argued that:

They [the Beasties] got over to white kids because in their own mind they were the ' 80 s version of Led Zeppelin or Johnny Rotten. But they were about excess, destruction in their personal lives and careers, and that was a very potent thing in the middle of the ' 80 s, when there were all these hair bands dominating TV, and everything had got very safe, very packaged, very corny. (Bill Adler quoted in Batey 1998, p. 66)

However, the Beasties' excess was itself very safe, which is what made it so generally attractive. The group repackaged an inherited knowledge of the Jewish lack of civility as a practice of incivility with which white college teens looking for a fantasy of rebellion could identify.

As it happens, pace Yauch, it would seem that the Beasties' practice of incivility began earlier than 'Fight', on their 1985 Virgin Tour with Madonna. In spite of having two hit singles, this was Madonna's first tour. Simmons managed to get the Beasties on as her support act. While the Beasties and Madonna had never met, as Horovitz points out, she knew the act she was getting because 'we all used to hang out at Dancetaria so we knew about each other' (Adam Horovitz quoted in Ogg 2002, p.56). Madonna must have thought that the group would compliment her own performance. 
Ogg writes that: 'The tour . . . established [the Beasties'] reputation for mayhem, which was more than tacitly encouraged by Simmons' (Ogg 2002, p. 56). It is not only Jews who have a knowledge of life without civility; so do, in this case, African Americans and those descended from Italian peasant migrants. ${ }^{14}$ Madonna's mother died when she was five. Madonna's paternal grandfather, Gaetano Ciccone, and his bride, Michaelina Dijulio, migrated to the United States from the central Italian village of Pacentro in 1920. Her biographer, Douglas Thompson, writes that Madonna 'has drops of French and Dutch blood, gallons of Italian and is all-American' (Thompson 2002 , p. 9). Her audience, the respectable, middle-class, white teen sisters of the boys who eighteen months later would take 'Fight' seriously, hated, as Gueraseva puts it, 'these three sweaty, potty-mouthed, obnoxious, pimply young guys' (Gueraseva 2005, p. 53), and the Beasties played up to it. Madonna, ever the performer, as migrants and their immediate descendents have to be to assimilate, and no stranger to incivility herself as her later book of erotic photographs, Sex, published in 1992, demonstrates, loved the Beasties:

They were very bad boys - they said 'fuck' all the time onstage. The audience always booed them, and they always told everyone to fuck off. I just loved them for that. I couldn't understand why the audience hated them - I thought they were adorable. I think I made out with Adam Yauch once in their dressing room. (Madonna quoted in Light 2005, p. 67)

Having watched them booed throughout their performance at Madison Square Garden, Adler says he thought: 'These guys are great. They're gonna be fine' (quoted in Light 2005, p. 68). As her support, the Beasties were a great foil for Madonna because they could perform as the safe, uncivil version of her. On that tour the group could bring their Jewish memory of a lack of civility and combine it with their own middle-class knowledge of white, male, teen incivility to generate a performance that would form the basis for their own success - and would have had that great uncivil Jewish comic of the 1950s, Lenny Bruce, rolling in the aisle with laughter. Madonna's early-teen, female audience could vent their anger at the Beasties who were acting like their brothers and then luxuriate in the feminine reassurance offered by Madonna in her persona as the Material Girl:

\section{The Americaness of the Jewish Beasties}

Earlier I quoted Biale et al. describing Jews as simultaneously insiders and outsiders in American society. I have been arguing that one way of thinking about this by the 1980s is that Jews were constructed as white and accepted but that this acceptance was problematised by the ( self-)knowledge of Jews as being Jews. I want to illuminate this description by looking at what is usually considered to be the strangest track on Licensed To Ill, 'Paul Revere'. Batey, for example, can only say about it that it is 'just plain odd' (Batey 1998, p. 46). This understanding is reinforced by Run's contribution which was to record the 808 drum-machine beat backwards. I have already mentioned 'Paul Revere' in my discussion of the 'Three Bad Jewish Brothers' skit. Where 'Jewish' was added for the skit it was left out of the phrase in 'Paul Revere'.

As the narrative unfolds we are told that Mike D. had a horse called Paul Revere. Now, Paul Revere is celebrated as one of the heroes of the American War of Independence. On 18 April 1775, he rode to Lexington to warn Samuel Adams and John Hancock that the British troops were coming to arrest them. Naming his horse after Revere puts Mike D. in Revere's place on the horse, which suggests a rather anxious 
assertion of being American - drawing on a figure from before independence, before there were Americans, a person who mythically helped to bring America into existence. A little later we are told that Mike D has a baseball hat - another signifier of American-ness for a Jew who is uncertainly American.

It is helpful to compare 'Paul Revere' with a much earlier track by another Jew, Bob Dylan's ‘Bob Dylan's 115th Dream'. Both tracks have a dream-like quality, being very dense and allusive. Both can be read as disguising their Jewish preoccupations. The Dylan track was released on Bringing It All Back Home in 1965. With its rhythmic accentuation and almost spoken form, 'Dream', along with 'Maggie's Farm' off the same album, is perhaps the closest Dylan came to precursing rap. Both tracks owe much to the 'talking blues' tradition. There are a number of echoes of earlier songs in 'Paul Revere's' lyrics. One is of Dylan's 'Eternal Circle'. Where MCA raps: 'You think this story's over but it's ready to begin', Dylan has a refrain which changes from verse to verse and which starts as: 'But the song it was long and I'd only begun'. ${ }^{15}$

In 'Paul Revere', Mike D is already in the United States, but is an outlaw being chased by the sheriff who meets up with MCA and Ad-Rock and holds up a bar. Thus all three become outlaws. By contrast, Dylan's first person narrator can be read as a migrant who is coming to America. The singer sings that he is 'riding on the Mayflower' which, if we think of the singer as Dylan, suggests an anxious Jewish assertion of puritan, Anglo-American identity. However, a displaced Semitism comes through when the singer yells for 'Captain Arab' rather than Herman Melville's Captain Ahab from one of the canonical American novels, Moby Dick. Here, the Arab stands in for the Jew. ${ }^{16}$ When they reach land the singer tells us: 'I think I'll call it America', which, again, bearing in mind that Dylan is Jewish, suggests the excluded migrant's fantastic attempt at inclusion by means of total, pre-emptive appropriation. This is echoed in Mike D's naming of his horse. Dylan/the singer and his shipmates have a dreadful reception in this new-found land including being thrown into gaol from which Dylan/the singer escapes becoming a fugitive like Mike D. Dylan/the singer sets sail and leaves, passing Columbus arriving. This Jew's pre-emptive attempt to appropriate America and, by this means, become an insider has failed, as it was always doomed to.

I will not pursue this dual reading. My purpose is to suggest the different experiences of the insider/outsider dynamic of American Jews a generation apart. Dylan is of the Beasties' parents' generation. Billig insightfully writes about Dylan that his 'music was that of an outsider posing as a dispossessed insider' (Billig 2000, p. 131) and this certainly agrees with the reading of 'Dream' that I have been developing. When Dylan grew up, Jews were not yet (fully) constructed as white. A generation later, 'Paul Revere' suggests the Beasties feel American, for which we should read white, that is experiencing themselves as insiders but, as outlaws the Beasties, as Jews, remain outsiders. In its content, 'Paul Revere' can be read as the most overtly Jewish of the Beasties' songs from this period.

In September 1986, as part of the promotion for Licensed To Ill, Rubin shot a television commercial to promote the Beasties. In it, with 'Yankee Doodle' playing in the background, 'George Washington' signs the Constitution and then gives the pen to 'Abraham Lincoln'. At this point the music changes to 'Fight', the Beasties appear and Ad-Rock grabs the pen scrawling his own signature on the Constitution, spilling ink on the document in the process. The Beasties then run off. At the end, the Beasties' faces are superimposed on the images of the presidents on Mount Rushmore and a voiceover states: 'Beastie Boys: American rock'n'roll' ${ }^{17}$ If we couldn't guess from the 
overwhelming whiteness of the advertisement, the description of the Beasties in terms of rock rather than rap tells us that the advertisement is aimed at a white audience. The dominant reading is of white male teens playing up. It is, like 'Fight' itself, a carnivalesque fantasy of rebellion - not revolution because, reassuringly, Ad-Rock does sign the Constitution - here displaced from the family to the nation. It is a fantasy of teen empowerment. Washington and Lincoln epitomise American patriarchy, as do the presidents on Mount Rushmore. The eruption of the Beasties suggests not the end of patriarchy but its replacement by (white) teenage males who know how to party.

Again, though, there is a sublimated Jewish reading, and it is intriguing to note that Lyor Cohen, the Jew who worked for Rush and went on to manage Def Jam, was supposed to play Lincoln until other commitments made this impossible. In this reading we have the Jewish Beasties gatecrashing the signing of the Constitution and asserting their presence not just in America but, with Ad-Rock's signature, as a foundational element in the formation of America. This should remind us of Dylan's 'Bob Dylan's 115th Dream' and Dylan's even more fundamental, fantastic preemption of Columbus' 'discovery' of America. In the Beasties' Jewish fantasy of homeliness in America, even the Mount Rushmore sculptures become Jewish. The United States is given a Jewish presidential history when, of course ( sic), a Jew has never reached that exalted position. Read from this Jewish perspective, 'Fight' becomes an assertion of Jewish presence, and an attempt to acknowledge that presence as accepted as a key element in the national, racial organisation of the United States. Read in this way, the advertisement situates the Jewish desire for legitimation within the American nation-state from a position similar to the insider/outsider status evinced in 'Paul Revere'.

\section{Conclusion}

After Licensed to Ill, the Beasties fell out with both Rubin and Simmons, left Def Jam, moved to Los Angeles and, with the Dust Brothers, made Paul's Boutique, an album with very different qualities to Licensed to Ill and which is now, along with De La Soul's 3 Feet High and Rising, often regarded as epitomising the possibilities of sampling. But that is a different Jewish story for another time. In this article I have focused on the Beasties' early work. I have wanted to discuss how the group were positioned as white when viewed from an African-American perspective but accepted as legitimate hip hop artists because, unlike later white artists, they did not attempt to mimic black rappers. In this context, there were times when the power relations between black and white Americans came to the fore, such as when the Beasties addressed a black audience as 'niggers'.

At the same time, the group's Jewishness enabled them to be located ambiguously in relation to whiteness. The Beasties could use their Jewishness, consciously or not, to distance themselves from white American culture. One example of this was the voice used by the group members. While this could be read as white, it could also be read as 'Jewish'. The group's incivility, a trait of white teen rock groups, can be read as having its roots in a history of Jewish incivility. Similarly, the Beasties' anxious preoccupation with their masculinity, including their penis size, can be understood as an expression of the historical feminisation of male Jews which, in the United States, has surfaced in the image of the effeminate, nerdish nebbish, often typified in Woody Allen's early film characters. 
I have argued, from a Jewish point of view, that while the Beasties' relationship with hip hop and Black audiences positioned the group as white, it was, as Simmons understood, their Jewishness which was a foundation for the group's success. Their Jewishness enabled the group to be a bridge between African-American and white popular musics. Performing between two cultures, the Beasties were read by black audiences in terms of their ability to rap. The performative quality of the Beasties, their use of elements of the Jewish stereotype, expresses the ambiguous position of Jews in American whiteness. The Beasties, like American Jews generally, are within whiteness but are not-quite-white. This positioning enabled the Beasties to play with expectations of whiteness such as their performance of a version of white teen deviance to white audiences on the Madonna tour. At times the Beasties performance of whiteness became the real thing just as, at times, American Jews are accepted as white. Thus, the Beasties' music, most obviously '(You Gotta) Fight For Your Right (To Party)', could be read either literally or as a humorous parody of white, male teen behaviour.

We need to remember that the Beasties are not sui generis. They come out of a century-long tradition in which Jews have positioned themselves in the entertainment gap between African Americans and whites in the United States. This positioning has not been benign. Rather, it has been caught up in a web of power relations. Today, this positioning takes place in different ways, and for different cultural purposes, than it was in the past, but it is still being done. Jews are no longer migrants striving to be accepted into American society. While they are accepted as American, in the same way African Americans are, they remain not fully accepted as 'white'.

\section{Endnotes}

1. Michael Diamond tells this story in the liner booklet for the Beastie Boys' retrospective of their early hardcore days, Some Old Bullshit.

2. All this information comes from Stacy Gueraseva (2005, pp. 3-9).

3. Graffiti Rock screened on WPIX, Channel 11, in New York in 1985. Only the premiere was ever made.

4. Simmons' relationship with Jews has continued right through his business career. George notes that: 'Much of Russell's business growth has come from bonding with prominant Jewish business figures in the entertainment industry' (George 1998, p. 84).

5. For a critical discussion of 3rd Bass, see Lynch (2005). This is a Masters thesis at North Carolina State University. Lynch has little to say about 3rd Bass' Jewishness but argues that Serch and Nice 'adopt the dialect and vernacular of Black Brooklyn and Queens youth' (ibid., p. 22). She goes on to compare 3rd Bass with the minstrel tradition.

6. We should note here the semiotic complexity of McLaren's use of 'Buffalo Gals'. We have a Jewish entrepreneur using a minstrel song with music that probably has a white, English history and introducing elements of Black hip hop into it. The writer, who worked with the Virginia Serenaders, was John Hodges. In blackface he called himself Cool White. The liner notes for the album tell us that the track was, 'recorded with the World's Famous Supreme Team and Zulu singers backing them up with the words "She's Looking Like a Hobo" '. It is unclear if these were actually Zulus or members of Afrika Bambaataa's Zulu Nation who get thanked at the end of the notes. Either way, the singers are Black. McLaren himself acts as the square dance caller. The track uses scratching and the notes explain what 'scratching' is. The album was produced by Trevor Horn who is white and English.

7. Jimmy Drescher, a member of Murphy's Law who supported the Beasties on the tour, quoted in Light (2005, p. 95). See also, Gueraseva (2005, p. 114).

8. The album was going to be called Don't Be a Faggot.

9. This Dr Dre is not the same Dr Dre as the Dr Dre (Andre Young) the rapper and producer with N.W.A. who subsequently co-founded Death Row Records and produced Snoop Doggy Dogg. The Dr Dre (Andre Brown) referred to here was in Original Concept and went on to co-host Yo! MTV Raps.

10. Rhonda Lieberman, whose work appears in Kleeblatt's Too Jewish collection, wrote a laudatory piece about 2 Live Jews in Art Forum in 1993. Her enjoyment of the group comes from the fact that 2 Live Jews are assertive about their Jewishness whereas, as Lieberman writes: 'While I heard that the Beastie Boys are Jewish, 
they don't sing about it all the time'. Lieberman goes on: 'Jewish rap struck me as a healing moment, one of many beautiful relationships possible between the various hues of our multicultural rainbow' (Lieberman).

11. Run-D.M.C.'s original demo for 'Slow and Low' was finally released on the re-released version of King of Rock in 2005.

12. Public Enemy acknowledged the track, and their difference from its sentiment, with their track, 'Party For Your Right To Fight' on their 1988 album, It Takes A Nation Of Millions To Hold Us Back.

13. I discuss the Jewishness of the Dictators further in 'Jews, punk and the Holocaust: from the Velvet Underground to the Ramones - the Jewish-American story' in Stratton (2005).

14. One obvious similarity between the incivility of early twentieth-century Jews and African Americans can be found in both groups nouveau riche fascination with ostentatious jewellery. Commenting on the ring belonging to Monroe Stahr, a Jewish character in Scott Fitzgerald's novel The Last Tycoon, Sander Gilman writes that: 'Part of the image of the Jew at the beginning of the twentieth century, rings are a sign of parvenu status. Stahr's ostentatious love of jewelry is a sign of how far he has come and how very far he must go to become a true member of modern society' (Gilman 1991, p. 176). This description fits well the use of jewellery by African-American rappers. This jewellery has become known as bling bling, now often shortened to bling. A useful background on the term comes from MTV News: 'The term, which is used to describe diamonds, jewelry and all forms of showy style, was coined by New Orleans rap family Cash Money Millionaires back in the late ' 90 s and started gaining national awareness with a song titled "Bling Bling" by Cash Money artist BG' ('Bling Bling').

15. It is also possible to hear an echo of the Grateful Dead's 'Friend of The Devil', from the band's 1970 album, American Beauty, a slice of white countrified Americana, in 'Paul Revere's 'Sheriff's posse on my tail' and the storyline about the sheriff being 'after me for what I did to his daughter' is reminiscent of Thin Lizzy's 'Leave This Town' off Renegade (1981). None of these white rock songs (though Phil Lynott, lead singer with Thin Lizzy had a Black Brazilian father) are conventional references for a rap song.

16. Dylan's idea for converting 'Ahab' to 'Arab' may have come from Ray Stevens' comedy song 'Ahab the Arab' released three years earlier in 1962.

17. This description is taken from Gueraseva (2005, p. 101).

\section{References}

Azoulay, K.G. 1997. Black, Jewish, and Interracial: Its Not the Color of Your Skin But the Race of Your Kin, and Other Myths of Identity (Durham, Duke University Press)

Batey, A. 1998. Rhyming and Stealing: A History of the Beastie Boys (London: Independent Music Press) Beastiemania.com <http://www.beastiemania.com/songspotlight/show.php?s=cookiepuss\&band=b>, consulted 10 February 2006

Biale, D., Galchinsky, M., and Heschel, S. 1998. 'Introduction', in Insider/Outsider: American Jews and Multiculturalism, ed. D. Biale, M. Galchinsky and S. Heschel (Berkeley, University of California Press), pp. 1-13

Billig, M. 2000. Rock'n'Roll Jews (Syracuse, NY, Syracuse University Press)

" "Bling Bling" added to Oxford English Dictionary', MTV News, 30 April 2003 <http:/ / www.mtv.com/ news/articles/1471629/20030430/bg.jhtml?headlines=true>, consulted 10 February 2006

Boyarin. D. 1997. Unheroic Conduct: The Rise of Heterosexuality and the Invention of the Jewish Man (Berkeley, University of California Press)

Brodkin, K. 1998. How Jews Became White Folks \& What That Says About Race in America (New Brunswick, NJ, Rutgers University Press)

Diehl, M. 1999. 'Pop rap', in The Vibe History of Hip Hop, ed. Alan Light (New York, Three Rivers Press), pp. 121-33

Erlewine, S.T. 'Run-D.M.C.: Biography', Allmusic Guide, <http://www.allmusic.com/cg/amg.dll?p= amg\&sql=11:mmeq97yjkr5t $\sim \mathrm{T} 1>$, consulted 10 February 2006

'Run-D.M.C.: Overview', Allmusic Guide, <http://www.allmusic.com/cg/amg.dll?p=amg\&sql= 10:j13zefwkhgfo $>$, consulted 10 February 2006

George, N. 1998. Hip Hop America (London, Penguin)

Gilman, S.L. 1991. The Jew's Body (New York, Routledge)

Greenberg, S. 1999. 'Sugar Hill Records', in The Vibe History of Hip Hop, ed. Alan Light (New York, Three Rivers Press), pp 23-34

Gueraseva, S. 2005. Def Jam, Inc.: Russell Simmons, Rick Rubin, and the Extraordinary Story of the World's Most Influential Hip Hop Label (New York, One World Ballantine)

Jacobson, M.F. 1998. Whiteness of a Different Color: European Immigrants and the Alchemy of Race (Cambridge, MA, Harvard University Press)

Kleeblatt, N. 1996. 'Passing' into multiculturalism', in Too Jewish? Challenging Traditional Identities, ed. N. Kleeblatt (New York, Jewish Museum), pp. 3-38 
Krims, A. 2000. Rap Music and the Poetics of Identity (New York, Cambridge University Press)

Lieberman, R. 1993. 'Miami Fantasia, part 2 - Jewish rap music', <http://www.findarticles.com/p/ articles/mi_m0268/is_n7_v31/ai_13904316>, consulted 10 February 2006

Light, A. 2005. The Skills to Pay the Bills: The Story of the Beastie Boys (New York, Three Rivers Press)

Lynch, K. 2005, The Minstrelization of Hip Hop and Spoken Word Authenticity: Expressions of Postmodern Blackness, MA thesis, North Carolina State University, <http://www.lib.ncsu.edu/theses/available/ etd-07252005-092219/unrestricted/etd.pdf>

Neal, M., and Forman, M. 2004, That's the Joint!: The Hip Hop Studies Reader (New York, Routledge)

Odell, M. 2004. 'The greatest songs ever! Fight for Your Right', Blender: The Ultimate Guide to Music and More, <http:/ / www.blender.com/guide/articles.aspx?id=650>, consulted 10 February 2006

Ogg, A. 2002. The Men Behind Def Jam: The Radical Rise of Russell Simmons and Rick Rubin (London, Omnibus Press)

Prell, R.E. 1999. Fighting to Become Americans: Jewws, Gender and the Anxiety of Assimilation (Boston, MA, Beacon Press)

Rogin, M. 1996. Blackface White Noise: Jewish Immigrants in the Hollywood Melting Pot (Berkeley, University of California Press)

Rose, T. 1994. Black Noise: Rap Music and Black Culture in Contemporary America (Hanover NH, Wesleyan University Press)

Rubin, M. 1999. 'The Beastie Boys', in The Vibe History of Hip Hop, ed. Alan Light (New York: Three Rivers Press), pp. 126-7.

Simmons, R. Interview with C. Muhammad at Black Electorate.Com, <http://www.blackelectorate.com/ articles.asp?ID=790>, consulted 10 February 2006

Stratton, J. 2000. Coming Out Jewish: Constructing Ambivalent Identities (London, Routledge)

2005. 'Jews, punk and the Holocaust: from the Velvet Underground to the Ramones - the JewishAmerican story', Popular Music, 24/1, pp. 79-115

2007. 'Punk, Jews and the Holocaust - the English Story', in Shofar, special issue, ed. Mikel Koven, 26/4, pp. 124-49.

Thompson, D. 2002. Madonna: Queen of the World (London, John Blake Publishing)

\section{Discography}

2 Live Crew, As Nasty As They Wanna Be. Luke. 1989.

2 Live Jews, Kosher as They Wanna Be. Kosher. 1990

Beastie Boys, Licensed to Ill. Def Jam. 1986

Paul's Boutique. Capitol. 1989

Some Old Bullshit. Grand Royal. 1994

De La Soul, 3 Feet High and Rising. Tommy Boy. 1989

Dictators (The), The Dictators Go Girl Crazy! Epic. 1975

Bob Dylan, Bringing It All Back Home. Columba. 1965

Malcolm McLaren, Duck Rock. Island. 1983

Motörhead, No Sleep 'Til Hammersmith. Bronze. 1981

Public Enemy, It Takes a Nation of Millions to Hold Us Back. Def Jam. 1988

Run D.M.C., King of Rock. Profile. 1985

Raising Hell. Profile. 1986

Vanilla Ice, To the Extreme. SBK. 1990. 
Reproduced with permission of the copyright owner. Further reproduction prohibited without permission. 